\title{
ЛИСИЙ ІГОР,
}

аспірант Прикарпатського національного університету

імені Василя Стефаника, м. Івано-Франківськ

\section{ТУРИСТИЧНА ОЦІНКА ІСТОРИКО-КУЛЬТУРНОГО ПОТЕНЦІАЛУ ЗАМКОВИХ СПОРУД ІВАНО-ФРАНКІВСЬКОЇ ОБЛАСТІ}

У статті на основі авторської методики проведено туристичну оцінку історико-культурного потенціалу збережених пам'яток замкового будівництва Івано-Франківської області, що дало змогу визначити їх рівень атрактивності та перспективи залучення для потреб туристично-рекреаційної галузі. Автором визначено пріоритетні шляхи використання замків регіону в туризмі, які полягають у збільшенні заходів подієвого туризму, розробці нових туристично-рекреаційних маршрутів на їх основі та музеєфікації збережених фрагментів замків.

Ключові слова: туристична оцінка; замок; замкова споруда; Івано-Франківська область.

Постановка проблеми та стан її вивчення. На сучасному етапі розвитку суспільства з кожним роком усе більшу історико-культурну, пізнавальну, навчально-виховну та туристично-рекреаційну роль відіграють пам'ятки замкового будівництва, які є пережитками різних історичних епох та елементами культурного самоусвідомлення корінних етносів. У наш час, коли людство стикається 3 проблемними аспектами всезагальної глобалізації та втрати етнокультурної ідентичності, ці історичні об'єкти є фрактором збереження цілих націй, оскільки їх вдала репрезентація дозволяє відтворити деякі елементи історичних подій. Саме замкові споруди є одним із чинників туристичної популяризації Івано-Франківщини, навіть незважаючи на мізерну кількість таких пам'яток та незадовільний стан їх збереженості. Однак без об'єктивної комплексної оцінки історико-культурного потенціалу замкових комплексів області суттєво ускладнюється процес їх ефективного туристично-рекреаційного використання. Зважаючи на це, якісна туристична оцінка об'єктів замкового зодчества регіону виступає одним із пріоритетних завдань розвитку туризму, покликаним оптимізувати не тільки процедуру залучення замкових ансамблів у туристичну галузь, але й шляхи їх збереження та передачі наступним поколінням.

Оцінка шляхів використання історико-культурного потенціалу Івано-Франківської області для потреб туризму завжди була в полі зору теоретиків туризму, адже в останні роки спостерігається підвищена увага до пізнання історико-культурних особливостей цього регіону. Проте проблематика туристичної оцінки замкових споруд як вагомої складової історико-культурної спадщини Івано-Франківщини $є$ малодослідженою, оскільки ґрунтовні наукові пошуки в цій сфері розпочалися не так давно. Тому питання комплексної оцінки об'єктів замкового будівництва Івано-Франківської області досі недостатньо вивчене, що пов'язано з необхідністю врахування в оцінюванні багатьох чинників та факторів. Засадничі аспекти туристичної оцінки історико-культурних ресурсів знайшли своє відображення в працях О. Бейдика [2], В. Клапчука [4], О. Клапчук [5], І. Костащука [6], В. Кравціва [7], а власне пам'яток замкового зодчества - лише в наукових напрацюваннях Н. Аніпко [1], А. Жердьова [3], А. Федорука [8], Н. Шиндлярської [9] та ін. Відсутність єдиного наукового підходу до туристичної оцінки замкових споруд та недосконалість існуючих методик через неврахування багатьох ключових критеріїв потребує подальших досліджень у цій сфрері та розробки нових оціночних шкал.

Мета статті - здійснення комплексної оцінки туристичної привабливості збережених пам'яток замкового будівництва Івано-Франківської області на основі авторської методики та аналіз перспектив використання цих об'єктів у галузі історико-культурного туризму.

Виклад основного матеріалу. Івано-Франківська область, яка має величезний матеріальний та духовний історико-культурний потенціал, не виділяється значною кількістю збережених замкових споруд. До наших днів дійшли лише 5 таких об'єктів: Галицький (XVI ст.), Маріямпільський (XVII ст.), Раковецький (XVII ст.), Чернелицький (XVII ст.) та Пнівський (XVI ст.) замки, які все ж володіють потужним історико-культурним потенціалом, що може стати передумовою повномасштабної туристичної адаптації цих пам'яток.

Для визначення туристичного потенціалу та рівня атрактивності замкових комплексів Івано-Франківщини було розроблено авторську методику оцінки, засновану на комплексному підході, що включає чотири групи складових: природно-географічна, історико-культурна, інфраструктурна та рекламно-інформаційна. Кожна з цих груп має по 5 показників оцінки. Згідно з кожним із критеріїв об'єкт замкового будівництва може отримати від 1 до 5 балів, а максимально можливий загальний показник за всіма елементами - 100 балів (табл. 1).

Наступним етапом оцінки є визначення загального ступеня можливостей туристичного використання замкової споруди, для чого було застосовано таке ранжування за сумарною кількістю балів:

0-20 балів - пам'ятка замкового будівництва непридатна для туристично-рекреаційного використання;

21-40 балів - замкова споруда слабоінтегрована в туристично-рекреаційну галузь;

41-60 балів - об'єкт використовується в туризмі на середньому рівні;

61-80 балів - замок має високий рівень туристичнорекреаційної адаптації;

81-100 балів - потенціал пам'ятки замкового зодчества максимально використовується в індустрії туризму. 
Таблиця 1. - Шкала туристичної оцінки пам'яток замкового будівництва

\begin{tabular}{|c|c|c|c|c|c|c|}
\hline \multirow{2}{*}{\multicolumn{2}{|c|}{ Критерії оцінки }} & \multicolumn{5}{|c|}{ Бали } \\
\hline & & 1 & 2 & 3 & 4 & 5 \\
\hline \multirow{5}{*}{ 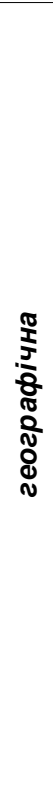 } & $\begin{array}{l}\text { Орографічна } \\
\text { специфіка } \\
\text { побудови }\end{array}$ & $\begin{array}{c}\text { Об'єкт } \\
\text { розм іщений на } \\
\text { низовині } \\
\text { (до 200 м) }\end{array}$ & $\begin{array}{l}\text { На височині } \\
(200-500 \text { м) }\end{array}$ & $\begin{array}{c}\text { У межах } \\
\text { плоскогір'я } \\
(500-1000 \text { м) }\end{array}$ & $\begin{array}{l}\text { У низьких } \\
\text { горах (1000- } \\
2000 \text { м) }\end{array}$ & $\begin{array}{c}\text { У високих } \\
\text { горах (понад } \\
2000 \text { м) }\end{array}$ \\
\hline & $\begin{array}{l}\text { Гідрологічні } \\
\text { особливості } \\
\text { розташування }\end{array}$ & $\begin{array}{l}\text { Немає гідроло- } \\
\text { гічних об'єктів }\end{array}$ & $\begin{array}{c}\text { Пам'ятка } \\
\text { знаходиться } \\
\text { поблизу ставка }\end{array}$ & $\begin{array}{c}\text { Замок } \\
\text { розм іщений } \\
\text { поблизу } \\
\text { водосховища }\end{array}$ & $\begin{array}{c}\text { Пам'ятка } \\
\text { знаходиться } \\
\text { поблизу рінки }\end{array}$ & $\begin{array}{c}\text { Замок } \\
\text { знаходиться на } \\
\text { березі моря }\end{array}$ \\
\hline & $\begin{array}{l}\text { Заповідна } \\
\text { характе- } \\
\text { ристика } \\
\text { території }\end{array}$ & $\begin{array}{c}\text { Немає } \\
\text { природно- } \\
\text { заповідних } \\
\text { територій }\end{array}$ & $\begin{array}{c}\text { Замок } \\
\text { знаходиться } \\
\text { поблизу } \\
\text { заповідного } \\
\text { урочища }\end{array}$ & $\begin{array}{c}\text { Замок } \\
\text { побудований } \\
\text { поблизу } \\
\text { заказника }\end{array}$ & $\begin{array}{c}\text { Замок } \\
\text { знаходиться у } \\
\text { межах } \\
\text { регіональ ного } \\
\text { ландшафтного } \\
\text { парку } \\
\end{array}$ & $\begin{array}{c}\text { Об'єкт } \\
\text { розташований } \\
\text { у межах } \\
\text { національного } \\
\text { природного } \\
\text { парку } \\
\end{array}$ \\
\hline & $\begin{array}{l}\text { Наявність } \\
\text { об'єктів } \\
\text { садово- } \\
\text { паркового } \\
\text { мистецтва }\end{array}$ & $\begin{array}{c}\text { Немає об'єктів } \\
\text { садово- } \\
\text { паркового } \\
\text { мистецтва }\end{array}$ & $\begin{array}{l}\text { Збережені } \\
\text { окремі } \\
\text { елем енти }\end{array}$ & $\begin{array}{c}\text { Фрагментарне } \\
\text { збереження } \\
\text { садово- } \\
\text { паркового } \\
\text { об'єкта }\end{array}$ & $\begin{array}{c}\text { Ревіталізовані } \\
\text { об'єкти } \\
\text { садово- } \\
\text { паркового } \\
\text { будівництва }\end{array}$ & $\begin{array}{c}\text { Повністю } \\
\text { збережена } \\
\text { пам'ятка } \\
\text { садово- } \\
\text { паркового } \\
\text { мистецтва }\end{array}$ \\
\hline & $\begin{array}{l}\text { Ландшафтна } \\
\text { специфіка } \\
\text { розташу- } \\
\text { вання }\end{array}$ & $\begin{array}{l}\text { Антропо- } \\
\text { генний } \\
\text { ландшафтт }\end{array}$ & $\begin{array}{l}\text { Рівнинний } \\
\text { ландшафтт }\end{array}$ & $\begin{array}{c}\text { Материковий } \\
\text { аквальний } \\
\text { ландшаффт }\end{array}$ & $\begin{array}{l}\text { Приморський } \\
\text { аквальний } \\
\text { ландшаффт }\end{array}$ & $\begin{array}{l}\text { Гірський } \\
\text { ландшафт }\end{array}$ \\
\hline \multirow{5}{*}{ 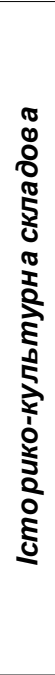 } & $\begin{array}{l}\text { Фізична } \\
\text { збереженість }\end{array}$ & Руїни & $\begin{array}{c}\text { Збережені } \\
\text { окремі } \\
\text { фрагменти } \\
\text { споруди }\end{array}$ & $\begin{array}{c}\text { Збережені } \\
\text { ключові } \\
\text { елементи } \\
\text { будівлі }\end{array}$ & $\begin{array}{c}\text { Замок } \\
\text { перебудований }\end{array}$ & $\begin{array}{c}\text { Пам'ятка } \\
\text { відмінно } \\
\text { збережена }\end{array}$ \\
\hline & $\begin{array}{l}\text { Історична } \\
\text { значущість }\end{array}$ & $\begin{array}{c}\text { Замок } \\
\text { побудовано у } \\
\text { XVIII ст. }\end{array}$ & $\begin{array}{c}\text { Пам'ятку } \\
\text { споруджено в } \\
\text { XVII ст. }\end{array}$ & $\begin{array}{c}\text { Об'єкт } \\
\text { побудовано в } \\
\text { XVI ст. }\end{array}$ & $\begin{array}{c}\text { Замок зведено } \\
\text { в XV ст. }\end{array}$ & $\begin{array}{c}\text { Пам'ятку } \\
\text { споруджено } \\
\text { до XV ст. }\end{array}$ \\
\hline & $\begin{array}{l}\text { Культурна } \\
\text { цінність }\end{array}$ & $\begin{array}{c}\text { Відсутність } \\
\text { охоронного } \\
\text { номера }\end{array}$ & $\begin{array}{c}\text { Щойно виявле- } \\
\text { ний об'єкт } \\
\text { культурної } \\
\text { спадщини }\end{array}$ & $\begin{array}{c}\text { Пам'ятка } \\
\text { архітектури } \\
\text { м ісцевого } \\
\text { значення } \\
\end{array}$ & $\begin{array}{c}\text { Пам'ятка } \\
\text { архітектури } \\
\text { наці онального } \\
\text { значення } \\
\end{array}$ & $\begin{array}{c}\text { Об'єкт Світової } \\
\text { спадщини } \\
\text { ЮНЕСКО }\end{array}$ \\
\hline & $\begin{array}{l}\text { Архітектурно- } \\
\text { стильова } \\
\text { специфіка }\end{array}$ & $\begin{array}{c}\text { Первісна } \\
\text { відсутність } \\
\text { стильового } \\
\text { офрорм лення }\end{array}$ & $\begin{array}{c}\text { Архітектурно- } \\
\text { стильові } \\
\text { елементи не } \\
\text { збереглися }\end{array}$ & $\begin{array}{c}\text { Слабко } \\
\text { виражені } \\
\text { стильові } \\
\text { ознаки }\end{array}$ & $\begin{array}{c}\text { Виражені } \\
\text { ознаки одного } \\
\text { архітектурного } \\
\text { стилю }\end{array}$ & $\begin{array}{c}\text { Поєднання } \\
\text { ознак } \\
\text { декількох } \\
\text { архітектурних } \\
\text { стилів } \\
\end{array}$ \\
\hline & $\begin{array}{l}\text { Тип історичної } \\
\text { оборонної } \\
\text { системи }\end{array}$ & $\begin{array}{c}\text { Відсутність } \\
\text { елементів } \\
\text { оборонної } \\
\text { системи }\end{array}$ & $\begin{array}{c}\text { Дерев'яно- } \\
\text { земляні фрорми } \\
\text { укріплення }\end{array}$ & $\begin{array}{l}\text { Баштова } \\
\text { оборонна } \\
\text { система }\end{array}$ & $\begin{array}{l}\text { Бастейна } \\
\text { оборонна } \\
\text { система }\end{array}$ & $\begin{array}{l}\text { Бастіонна } \\
\text { оборонна } \\
\text { система }\end{array}$ \\
\hline \multirow{5}{*}{ 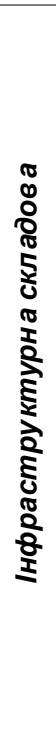 } & $\begin{array}{l}\text { Транспортна } \\
\text { доступність }\end{array}$ & $\begin{array}{c}\text { Об'єкт } \\
\text { розташований } \\
\text { поблизу дорі } \\
\text { місцевого } \\
\text { значення }\end{array}$ & $\begin{array}{l}\text { Неподалік } \\
\text { територі- } \\
\text { альних доріг }\end{array}$ & $\begin{array}{c}\text { Поблизу } \\
\text { регіональних } \\
\text { доріг }\end{array}$ & $\begin{array}{l}\text { Неподалік } \\
\text { національних } \\
\text { автодоріг }\end{array}$ & $\begin{array}{c}\text { Поблизу } \\
\text { міжнародних } \\
\text { автострад }\end{array}$ \\
\hline & $\begin{array}{l}\text { Наявність } \\
\text { закладів } \\
\text { готельного } \\
\text { господарства } \\
\end{array}$ & $\begin{array}{c}\text { Немає } \\
\text { закладів } \\
\text { розміщення }\end{array}$ & $€$ кемпінг & $\begin{array}{c}€ \text { туристичний } \\
\text { притулок }\end{array}$ & $€$ мотель & $€$ готель \\
\hline & $\begin{array}{l}\text { Наявність } \\
\text { об'єктів } \\
\text { ресторанної } \\
\text { індустрії }\end{array}$ & $\begin{array}{c}\text { Немає } \\
\text { закладів } \\
\text { ресторанного } \\
\text { господарства }\end{array}$ & $€$ д̈дальня & $€$ бар & $€$ кафе & $€$ ресторан \\
\hline & $\begin{array}{l}\text { Наявність } \\
\text { музейних } \\
\text { установ }\end{array}$ & $\begin{array}{c}\text { Відсутність } \\
\text { музейної } \\
\text { експозиції } \\
\end{array}$ & $\begin{array}{c}\text { Часткова } \\
\text { м узеєфікація } \\
\text { приміщень } \\
\end{array}$ & Музей-фрілія & $\begin{array}{c}\text { Незалежна } \\
\text { музейна } \\
\text { установа } \\
\end{array}$ & Скансен \\
\hline & $\begin{array}{l}\text { Наявність } \\
\text { точок продажу } \\
\text { сувенірної } \\
\text { продукції }\end{array}$ & $\begin{array}{c}\text { Немає ніяких } \\
\text { сувенірних } \\
\text { установ }\end{array}$ & $\begin{array}{c}\text { Сувеніри замку } \\
\text { продаються в } \\
\text { найближчому } \\
\text { торговельно- } \\
\text { інформаційному } \\
\text { центрі }\end{array}$ & $\begin{array}{c}\text { На території } \\
\text { зам ку є } \\
\text { сувенірна } \\
\text { лавка }\end{array}$ & $\begin{array}{c}\text { Замок має } \\
\text { власний } \\
\text { сувенірний } \\
\text { магазин }\end{array}$ & $\begin{array}{c}\text { Крамниця з } \\
\text { сувенірами } \\
\text { власного } \\
\text { виробництва }\end{array}$ \\
\hline
\end{tabular}


Продовження табл. 1

\begin{tabular}{|c|c|c|c|c|c|c|}
\hline \multirow{2}{*}{\multicolumn{2}{|c|}{ Критерії оцінки }} & \multicolumn{5}{|c|}{ Бали } \\
\hline & & 1 & 2 & 3 & 4 & 5 \\
\hline \multirow{5}{*}{ 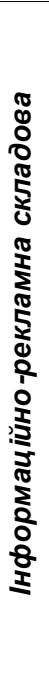 } & $\begin{array}{l}\text { Інтегрова- } \\
\text { ність у } \\
\text { туристичні } \\
\text { маршрути }\end{array}$ & $\begin{array}{c}\text { Об'єкт не } \\
\text { включений у } \\
\text { жоден } \\
\text { маршрут }\end{array}$ & $\begin{array}{c}\text { Замок включе- } \\
\text { ний у місцеві } \\
\text { м аршрути }\end{array}$ & $\begin{array}{c}\text { Пам'ятка } \\
\text { включена в } \\
\text { регіональні } \\
\text { маршрути } \\
\end{array}$ & $\begin{array}{c}\text { Об'єкт } \\
\text { включений у } \\
\text { національні } \\
\text { маршрути }\end{array}$ & $\begin{array}{c}\text { Замок } \\
\text { включений у } \\
\text { міжнародні } \\
\text { маршрути }\end{array}$ \\
\hline & $\begin{array}{l}\text { Організація } \\
\text { туристичних } \\
\text { промо- } \\
\text { кампаній }\end{array}$ & $\begin{array}{c}\text { До } 5 \text { заходів } \\
\text { на рік }\end{array}$ & $\begin{array}{c}\text { 5-10 подій } \\
\text { на рік }\end{array}$ & $\begin{array}{c}10-15 \\
\text { туристичних } \\
\text { заходів на рік }\end{array}$ & $\begin{array}{c}15-20 \text { заходів } \\
\text { на рік }\end{array}$ & $\begin{array}{c}\text { Більше } 20 \\
\text { заходів на рік }\end{array}$ \\
\hline & $\begin{array}{l}\text { Забезпе- } \\
\text { ченість } \\
\text { рекламними } \\
\text { матеріалами }\end{array}$ & $\begin{array}{l}\text { Немає реклам- } \\
\text { них матеріалів }\end{array}$ & $\begin{array}{c}\text { Туристичні } \\
\text { листівки про } \\
\text { об'єкт }\end{array}$ & $\begin{array}{c}\text { Замок } \\
\text { рекламується } \\
\text { в буклетах }\end{array}$ & $\begin{array}{c}\text { Пам'ятка } \\
\text { рекламується } \\
\text { в брошурах }\end{array}$ & $\begin{array}{c}\text { Є туристичні } \\
\text { путівники }\end{array}$ \\
\hline & $\begin{array}{l}\text { Науково- } \\
\text { інфрормаційна } \\
\text { вивченість }\end{array}$ & $\begin{array}{c}\text { Об'єкт не } \\
\text { описаний у } \\
\text { фахових } \\
\text { виданнях }\end{array}$ & $\begin{array}{c}\text { Пам'ятка } \\
\text { висвітлюється } \\
\text { в наукових } \\
\text { статтях }\end{array}$ & $\begin{array}{c}\text { Опубліковані } \\
\text { туристичні } \\
\text { посібники про } \\
\text { пам'ятку }\end{array}$ & $\begin{array}{c}\text { Опубліковані } \\
\text { наукові книги } \\
\text { про об'єкт }\end{array}$ & $\begin{array}{c}\text { Видані } \\
\text { монографії } \\
\text { туристичного } \\
\text { напрямку }\end{array}$ \\
\hline & $\begin{array}{l}\text { Насиченість } \\
\text { інформацією } \\
\text { мережі } \\
\text { Інтернет }\end{array}$ & $\begin{array}{c}\text { До } 5 \text { тис. } \\
\text { пошукових } \\
\text { резу ль татів }\end{array}$ & $\begin{array}{c}\text { 5-10 тис. } \\
\text { пошукових } \\
\text { результатів }\end{array}$ & $\begin{array}{l}\text { 10-25 тис. } \\
\text { пошукових } \\
\text { результатів }\end{array}$ & $\begin{array}{l}\text { 25-50 тис. } \\
\text { пошу кових } \\
\text { результатів }\end{array}$ & $\begin{array}{c}\text { Більше } 50 \text { тис. } \\
\text { пошуков их } \\
\text { результатів }\end{array}$ \\
\hline
\end{tabular}

Таким чином, туристичний аналіз історико-культурного потенціалу об'єктів замкового будівництва ІваноФранківської області показав, що 4 пам'ятки (Маріямпільський, Раковецький, Чернелицький та Пнівський замки) знаходяться на середньому рівні туристичної адаптації, а Галицький замок має високий рівень туристично-рекреаційної адаптації (табл. 2).

Аналізуючи розподіл балів по основних складових,

Таблиця 2. - Розподіл балів серед замкових споруд Івано-Франківської області

\begin{tabular}{|c|c|c|c|c|c|c|}
\hline \multirow{2}{*}{\multicolumn{2}{|c|}{ Критерії оц інк и }} & \multicolumn{5}{|c|}{ Бали } \\
\hline & & \multirow{2}{*}{$\begin{array}{c}\begin{array}{c}\text { Галицький } \\
\text { замок }\end{array} \\
2\end{array}$} & \multirow{2}{*}{$\begin{array}{c}\begin{array}{c}\text { Маріямпільський } \\
\text { замок }\end{array} \\
2\end{array}$} & \multirow{2}{*}{$\begin{array}{c}\begin{array}{c}\text { Раков ецький } \\
\text { замо к }\end{array} \\
2\end{array}$} & \multirow{2}{*}{$\begin{array}{c}\begin{array}{c}\text { Чернелиць кий } \\
\text { замок }\end{array} \\
2\end{array}$} & \multirow{2}{*}{$\begin{array}{c}\begin{array}{c}\text { Пнів ський } \\
\text { замок }\end{array} \\
2\end{array}$} \\
\hline \multirow{5}{*}{ 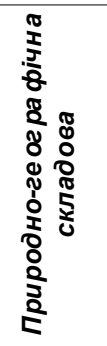 } & $\begin{array}{l}\text { Орографінна специфіка } \\
\text { побудови }\end{array}$ & & & & & \\
\hline & $\begin{array}{l}\text { Гідрологінні особливості } \\
\text { розташування }\end{array}$ & 4 & 4 & 4 & 1 & 1 \\
\hline & $\begin{array}{l}\text { Природоохоронна } \\
\text { характеристика території }\end{array}$ & 5 & 5 & 4 & 4 & 1 \\
\hline & $\begin{array}{l}\text { Наявність об'єктів садово- } \\
\text { паркового мистецтва }\end{array}$ & 2 & 4 & 1 & 1 & 1 \\
\hline & $\begin{array}{l}\text { Ландшафтна специфіка } \\
\text { м ісцерозташування }\end{array}$ & 3 & 3 & 3 & 1 & 2 \\
\hline \multirow{5}{*}{ 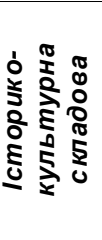 } & Фізична збереженість & 3 & 2 & 2 & 2 & 3 \\
\hline & Історична значущість & 3 & 2 & 2 & 2 & 3 \\
\hline & Культурна цінність & 4 & 3 & 4 & 4 & 4 \\
\hline & $\begin{array}{l}\text { Архітектурно-стиль ова } \\
\text { специфріка }\end{array}$ & 4 & 2 & 2 & 5 & 2 \\
\hline & $\begin{array}{l}\text { Тип історичної оборонної } \\
\text { системи }\end{array}$ & 4 & 5 & 3 & 5 & 4 \\
\hline \multirow{5}{*}{ 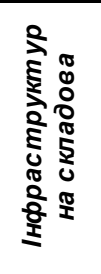 } & Транспортна доступність & 4 & 1 & 1 & 1 & 1 \\
\hline & $\begin{array}{l}\text { Наявність закладів } \\
\text { готельного господарства }\end{array}$ & 1 & 1 & 1 & 1 & 1 \\
\hline & $\begin{array}{l}\text { Наявність об'єктів } \\
\text { ресторанної індустрії }\end{array}$ & 1 & 1 & 1 & 1 & 1 \\
\hline & Наявність музейних установ & 1 & 1 & 1 & 1 & 1 \\
\hline & $\begin{array}{l}\text { Наявність точок продажу } \\
\text { сувенірної продукції }\end{array}$ & 2 & 1 & 1 & 1 & 1 \\
\hline \multirow{5}{*}{ 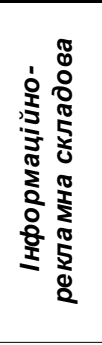 } & $\begin{array}{l}\text { Інтегрованість у туристичні } \\
\text { м аршрути }\end{array}$ & 4 & 2 & 3 & 3 & 3 \\
\hline & $\begin{array}{l}\text { Організація туристичних } \\
\text { промокам паній }\end{array}$ & 1 & 1 & 1 & 1 & 1 \\
\hline & $\begin{array}{l}\text { Забезпеченість рекламними } \\
\text { матеріалами }\end{array}$ & 4 & 2 & 3 & 3 & 3 \\
\hline & $\begin{array}{l}\text { Науково-інформ аційна } \\
\text { вивченість }\end{array}$ & 4 & 2 & 2 & 2 & 4 \\
\hline & $\begin{array}{l}\text { Насиченість інформацією } \\
\text { мережі Інтернет }\end{array}$ & 5 & 1 & 3 & 1 & 2 \\
\hline & Раз ом & 61 & 45 & 44 & 42 & 41 \\
\hline
\end{tabular}


слід зазначити, що Маріямпільський та Раковецький замки найбільшу кількість балів у процентному співвідношенні (40 і 32 \% відповідно від сумарної туристичної атрактивності кожного з об'єктів) отримали за природно-географічні особливості розташування, тоді як Галицький, Чернелицький та Пнівський - лише 26, 21 та $17 \%$ відповідно. Це означає, що природні умови розміщення перших двох пам'яток $є$ сприятливими для розвитку зеленого, екологічного, пізнавального видів туризму тощо. Історико-культурна складова туристичного потенціалу замків найбільшу кількість балів принесла Чернелицькому (43 \%) та Пнівському (39\%), що пояснюється оригінальними рисами архітектури цих споруд (застосування складних історичних типів оборонних систем та еклектичність архітектурних стилів побудови). У цій же категорії Галицький замок отримав 29,5 \%, Маріямпільський - 31 \% та Раковецький - 30 \% від загальної кількості одержаних балів. Надзвичайно низькі показники всі замкові споруди продемонстрували в інфраструктурній складовій. Так, найвищий бал отримав Галицький замок (9 балів, або $15 \%$ від загального туристичного потенціалу пам'ятки), усі інші замки - лише по 5 балів. Це пояснюється відносно слабким рівнем розвитку всіх видів туристичної інфрраструктури. Найвищу частку в інформаційно-рекламній складовій оцінки отримав Пнівський (32 \%), а найменшу Маріямпільський (18 \%) замки. Висока частка рекламно-інформаційних показників замку в Пневі пов'язана з наявністю значної кількості інформації (статей та книг, а також рекламних матеріалів) (рис. 1).

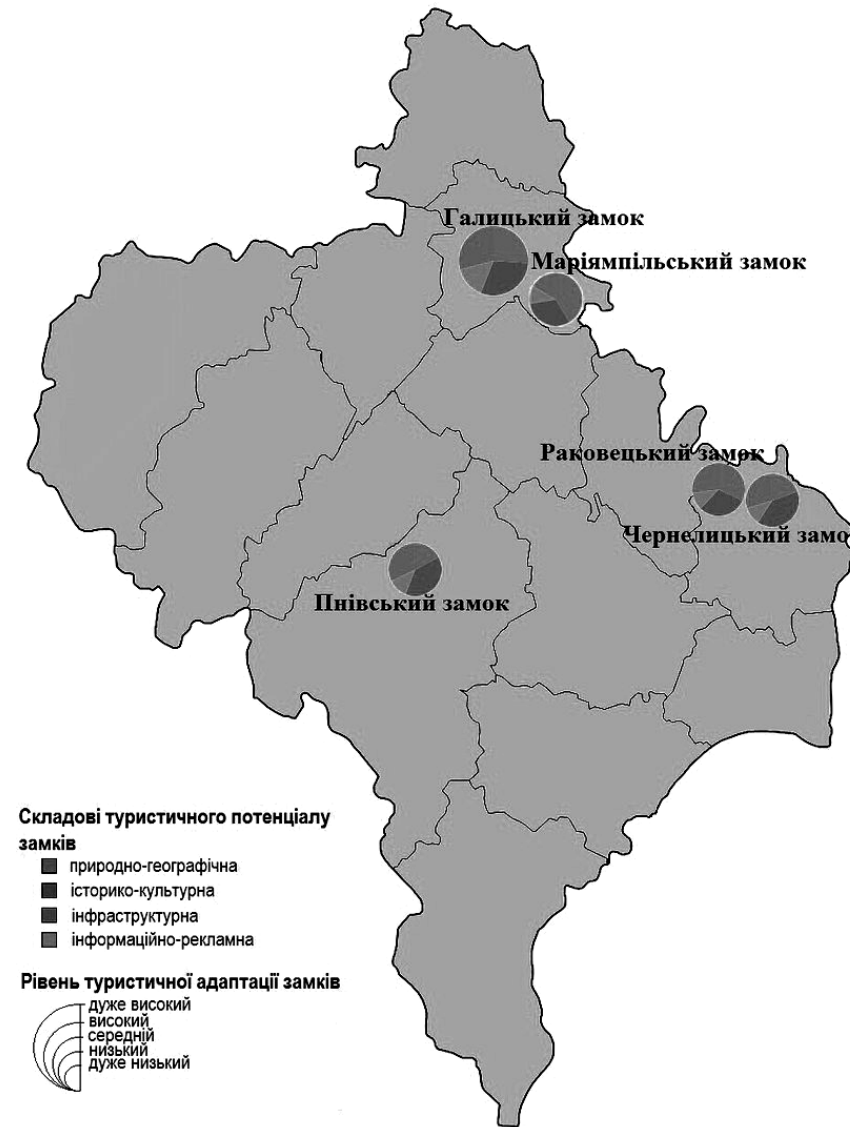

Рис. 1. Туристичний потенціал замкових споруд Івано-Франківської області.

Отже, одержані результати оцінки показують, що найбільш проблематичними аспектами туристичного використання замків Івано-Франківщини $€$ слабкий рівень розвитку туристичної інфраструктури (насамперед готельно-ресторанного фонду) та рекламно-інформаційного забезпечення, що не дозволяє розвивати ті види туризму, які пов'язані з багатоденним перебуванням. При цьому позитивними елементами туристичного потенціалу замкових споруд області $€$ їх унікальне природно-географічне положення (мальовничість ландшафтів, сприятлива екологічна ситуація та ін.) та оригінальна історико-культурна специфіка побудови замків (оригінальність архітектурно-оборонних систем), що є надзвичайно важливим для подальшої туристичної адаптації.

Проведена туристична оцінка історико-культурного потенціалу замкових споруд Івано-Франківської області дозволяє виділити ключові напрямки подальшої туристичної адаптації об'єктів:

1) залучити всі без винятку споруди для розвитку подієвого туризму, у першу чергу фестивального, а також спеціалізованих туристичних заходів (локальні та регіональні виставки та ярмарки, туристично-інформаційні акції). Такий підхід дасть змогу поширити інформацію про пам'ятки та підвищити туристичний інтерес до них;

2) розробити ряд тематичних інноваційних туристичних маршрутів, які стосуються історико-архітектурних аспектів замкового будівництва регіону та ознайомлюють зі збереженими замками Івано-Франківщини;

3) провести системну консервацію з подальшою музеєфікацією збережених фрагментів існуючих пам'яток, щоб уникнути подальшого руйнування та забезпечити регульований туристичний доступ до них.

\section{Висновки}

1. У статті представлено авторську методику туристичної оцінки пам'яток замкового будівництва, засновану на комплексному підході, що включає чотири групи складових: природно-географічну, історико-культурну, інфраструктурну та рекламно-інформаційну.

На підставі розробленої шкали оцінки та методу ранжування визначено загальний ступінь можливостей туристичного використання замкової споруди.

2. Проведена оцінка пам'яток замкового будівництва Івано-Франківщини показала, що 4 з 5 збережених замків на сучасному етапі не $є$ повноцінно адаптованими туристичними об'єктами, що в першу чергу пов'язано з відсутністю необхідної туристично-рекреаційної інфрраструктури та низьким рівнем розробки рекламно-інформаційного забезпечення. Необхідністю зали шається вдосконалення способів збереження та реставрації існуючих об'єктів, пошук нових шляхів залучення замкових споруд краю в туристичну галузь та розробка інноваційних тематичних туристичних маршрутів, щоб підвищити туристично-рекреаційний потенціал замкових споруд Івано-Франківської області.

\section{ЛIТЕРАТУРА}

1. Аніпко Н. П. Середньовічні замки і фортеці. Рекреаційно-туристське використання / Н. П. Аніпко // Краєзнавство, географрія, туризм. - 2011. - № 20. - С. 15-18.

2. Бейдик О. О. Рекреаційно-туристські ресурси України: методологія та методика аналізу, термінологія, районування / О. О. Бейдик. - К. : ВПЦ "Київський Університет", 2001. $395 \mathrm{c}$.

3. Жердьов А. Фортифрікаційні споруди у системі об'єктів туристсько-рекреаційної діяльності / А. Жердьов, В. Притков // Географія та туризм. - 2012. - Вип. 19. - С. 143-149.

4. Клапчук В. М. Методика оцінки туристично-рекреаційних ресурсів адміністративних районів Івано-Франківської області для стратегічних потреб розвитку туристично-рек- 
реаційної діяльності / В.М.Клапчук, О.О.Клапчук, М.В.Клапчук // Карпатський край. - 2013. - № 1 (3). - С. 119-132.

5. Клапчук О. О. Туристично-рекреаційні ресурси Львівської області: територіальна диференціація, оцінка, напрямки використання : автореф. дис. на здобуття наук. ступеня канд. геогр. наук : спец. 11.00.02 "Економічна та соціальна географія" / О. О. Клапчук. - Львів, 2011. - 20 с.

6. Костащук І. І. Методика оцінки сакрально-туристичних ресурсів регіону (на прикладі Чернівецької області) / І. І. Костащук // Науковий вісник ЧНУ. Серія "Географія". - 2010. Вип. 519-520. - С. 81-86.
7. Кравців В. С. Науково-методичні засади реформування рекреаційної сфери / В. С. Кравців, Л. С. Гринів, М. В. Копач, С. П. Кузик. - Львів : НАН України, 1999. - 78 с.

8. Федорук А. Т. Старинные усадьбы минского края / А. Т. Федорук. - Минск : Полифакт, 2000. - 416 с.

9. Шиндлярська Н. П. Оцінка туристичного потенціалу замкових споруд Тернопільської області та їх використання в туризмі / Н.П.Шиндлярська, С. О. Дем'яненко // Конструктивна географрія та раціональне використання природних ресурсів. - 2014. - № 10 (4). - С. 66-82.

Лысый Игорь,

аспирант Прикарпатского наџионального университета имени Василия Стефаника, г. Ивано-Франковск

\section{ТУРИСТИЧЕСКАЯ ОЦЕНКА ИСТОРИКО-КУЛЬТУРНОГО ПОТЕНЦИАЛА ЗАМКОВЫХ СООРУЖЕНИЙ ИВАНО-ФРАНКОВСКОЙ ОБЛАСТИ}

В статье на основе собственной методики проведена туристическая оценка историко-культурного потенциала сохранившихся памятников замкового строительства Ивано-Франковской области, что позволило определить их уровень аттрактивности и перспективы дальнейшего привлечения для нужд туристско-рекреационной отрасли. Автором определены приоритетные пути использования замков региона в туризме, которые заключаются в увеличении мероприятий событийного туризма, музеефикации и разработке новых туристскорекреационных маршрутов на их основе.

Ключевые слова: туристическая оценка; замок; замковое сооружение; Ивано-Франковская область.

Lysyi Igor,

graduate student, Vasyl Stefanyk Subcarpathian National University, Ivano-Frankivsk

\section{TOURIST ESTIM ATION OF HISTORICALAND CULTURAL POTENTIAL OF CASTLES IN THE IVANO-FRANKIVSK REGION}

The article is based on own methods of tourist estimation of historical and cultural potential of castle buildings in the Ivano-Frankivsk region to determine their level of attractiveness and prospects for needs of tourism and recreation industry. In the Ivano-Frankivsk region are five castles: in Halych (XVI century) Mariiampil (XVII century), Rakovets (XVII century), Chernelytsia (XVII century) and Pniv (XVI century), which have great historical and cultural potential and all of these buildings can be used for the tourist adaptation. Criteria of the tourist estimation of potential of castle complexes are built on an integrated approach that includes four groups of indicators: the natural and geographical location, historical and cultural features, infrastructure and advertising criteria. The tourist analysis of historical and cultural potential of castle constructions in the Ivano-Frankivsk region showed that 4 castles (in Mariiampil, Rakovets, Chernelytsia and Pniv) are at an average level of tourist adaptation and just castle in Halych has higher level of tourist and recreational adaptation. The author proposed following options for optimizing of the recreational use of castles, which are based on the tourist estimation: organization of new event activities, development of new tourist and recreational routes with castles and museumification.

Keywords: tourist estimation; castle; castle building; Ivano-Frankivsk region.

\section{REFERENCES}

1. Anipko N. P. (2011), Medieval castles and fortresses. Recreational and tourist use, Regional study. Geography. Tourism, 20 (May), pp. 15-18 (ukr).

2. Beidyk O. O. (2001), Recreational and tourist resources of Ukraine: methodology and methods of the analysis, terminology, zoning, University of Kyiv, Kyiv, 395 p. (ukr).

3. Zherdiov A. \& Prytkov V. (2012), Fortifications in the system of objects of tourist and recreational activities, Geography and Tourism, 19, pp. 143-149 (ukr).

4. Klapchuk V. M., Klapchuk O. O. \& Klapchuk M. V. (2013), Methods of assessing tourist and recreational resources of administrative districts of Ivano-Frankivsk region for the strategic needs of development of tourism and recreational activities, Carpathian region, 1 (3), pp. 119-132 (ukr)

5. Klapchuk O. O. (2011), Tourist and recreation resources of Lviv region: territorial differentiation, evaluation, ways of utilization, Abstract of thesis for the degree of candidate of geographical sciences in specialty 11.00 .02 "Economic and social geography", Lviv, 20 p. (ukr).

6. Kostashchuk I. I. (2010), Methods of estimation of sacred and tourist resources in the region (for example Chernivtsi region), Scientific Herald of Yurii Fedkovych Chernivtsi National University, 519-520, pp. 81-86. (ukr).

7. Kravtsiv V. S., Hryniv L. S., Kopach M. V. \& Kuzyk S. P. (1999), Scientific and methodological foundations of reform in the recreational sector, The National Academy of Sciences of Ukraine, Lviv, 78 p. (ukr).

8. Fedoruk A. T. (2000), Ancient palaces in the Minsk region, Polifakt, Minsk, 416 p. (rus)

9. Shyndliarska N. P. \& Demianenko S. O. (2014), The castle structures in the Ternopil region as a subject for developing of tourism, Constructive geography and rational use of natural resources, 10 (4), pp. 66-82 (ukr).

(C) Лисий Ігор

Надійшла до редакції 28.10.2015 